\title{
Empirical Bayesian selection of hypothesis testing procedures for analysis of digital gene expression data
}

\author{
Stan Pounds ${ }^{1}$, Cuilan Gao ${ }^{2^{*}}$ \\ From 12th Annual UT-ORNL-KBRIN Bioinformatics Summit 2013 \\ Buchanan, TN, USA. 22-24 March 2013
}

\section{Background}

Differential expression analysis of digital gene expression data involves performing a large number of hypothesis tests that compare the expression count data of each gene or transcript across two or more biological conditions. The assumptions of any specific hypothesis-testing method will probably not be valid for each of a very large number of genes. Thus, computational evaluation of assumptions should be incorporated into the analysis to select an appropriate hypothesis-testing method for each gene.

\section{Materials and methods}

Here, we generalize earlier work to introduce two novel procedures that use estimates of the empirical Bayesian probability (EBP) of overdispersion to select or combine results of a standard Poisson likelihood ratio test and a quasi-likelihood test for each gene. These EBP-based procedures simultaneously evaluate the Poisson-distribution assumption and account for multiple testing. With adequate power to detect overdispersion, the new procedures select the standard likelihood test for each gene with Poisson-distributed counts and the quasi-likelihood test for each gene with overdispersed counts.

\section{Results}

The new procedures outperformed previously published methods in many simulation studies. We also present a real-data analysis example and discuss how the framework used to develop the new procedures may be generalized to further enhance performance.

\footnotetext{
* Correspondence: cuilan-gao@utc.edu

${ }^{2}$ Department of Mathematics, University of Tennessee Chattanooga,

Chattanooga, TN 37403, USA

Full list of author information is available at the end of the article
}

\section{Authors' details}

'Department of Biostatistics, St. Jude Children's Research Hospital, Memphis, TN 38105, USA. ²Department of Mathematics, University of Tennessee

Chattanooga, Chattanooga, TN 37403, USA.

Published: 22 October 2013

doi:10.1186/1471-2105-14-S17-A21

Cite this article as: Pounds and Gao: Empirical Bayesian selection of hypothesis testing procedures for analysis of digital gene expression data. BMC Bioinformatics 2013 14(Suppl 17):A21.
Submit your next manuscript to BioMed Central and take full advantage of:

- Convenient online submission

- Thorough peer review

- No space constraints or color figure charges

- Immediate publication on acceptance

- Inclusion in PubMed, CAS, Scopus and Google Scholar

- Research which is freely available for redistribution
() Biomed Central

\section{Biomed Central}

